Journal of Applied Pharmaceutical Science Vol. 5 (02), pp. 120-122, February, 2015

Available online at http://www.japsonline.com

DOI: $10.7324 / J A P S .2015 .50217$

ISSN 2231-3354 (cc) BY-NC-SA

\title{
Localization of I gG Antigenic Sites in Goat Testicular Tissue
}

\author{
R. K. Sharma, A. K. Goyal \\ Reproductive Physiology Laboratory, Department of Zoology, Kurukshetra University, Kurukshetra, India.
}

\begin{tabular}{|c|c|}
\hline ARTICLE INFO & ABSTRACT \\
\hline Article history: & \multirow{8}{*}{$\begin{array}{l}\text { Testis is the tissue with immune privilege which is maintained by blood-testis barrier to protect autoimmunogenic } \\
\text { components of testis. IgG have binding affinity for CD16, CD } 32 \text { and CD64 receptors present on various immune } \\
\text { cells. Present study was conducted to investigate the IgG antigenic sites in the testicular tissue of goat. The } \\
\text { paraffin embedded histological sections were processed for immunohistochemistry protocol using Anti Mouse } \\
\text { IgG FITC conjugate antibodies and observed under fluorescence microscope. Strong reaction was observed in } \\
\text { epithelial lining of seminiferous tubule and moderate reaction was observed in lumen of seminiferous tubules and } \\
\text { interstitial space. Present studies indicate that the most of IgG antigenic components i.e. CD16, CD32 and CD64 } \\
\text { receptors were located in these sites. Current work will help in understanding of immune privilege and provide a } \\
\text { baseline on which further studies can be conducted. }\end{array}$} \\
\hline $4 / 12 / 2014$ & \\
\hline Revised on & \\
\hline Accepted o & \\
\hline Available online: $27 / 02 / 2015$ & \\
\hline Key wor & \\
\hline Testis, & \\
\hline $\begin{array}{l}\text { Immunohistochemistry, } \\
\text { Immune cells, Fluorescen }\end{array}$ & \\
\hline
\end{tabular}

\section{INTRODUCTION}

Testis is the tissue with immune privilege which is maintained by blood-testis barrier. This blood-testis barrier protects the various autoimmunogenic components of testis like spermatozoa which the body's immune system recognizes as foreign (Terayama et al., 2014). The blood-testis barrier formed by tight junctions of Sertoli cells which partitions the interstitial blood compartment of the testis from the adluminal compartment of seminiferous tubules (Terayama et al., 2014).

IgG play a critical role in defense. Various types of immune cells have receptors for the IgG. CD16 receptor present on the NK cells, macrophages, subpopulation of T-cells, immature thymocytes, neutrophils and stimulated eosinophils has binding affinity for $\mathrm{IgG}$ (Owen et al., 2013). CD32 receptor present on $\mathrm{B}$ cells, monocytes, macrophages, dendritic cells, and on endothelial cells also binds with Fc portion of IgG (Owen et al., 2013). In addition CD64 present on many immune cells also have high affinity for IgG (Owen et al., 2013). So the present

* Corresponding Author

Prof. R. K. Sharma, Reproductive Physiology Laboratory, Department of Zoology, Kurukshetra University, Kurukshetra-136119, India.

Email: rkskukz@gmail.com study was conducted to localize the antigenic sites for $\operatorname{IgG}$ in goat testis which in turn represent the sites where the components of immune system is actively presentand to locate sites of immune privilege where $\mathrm{IgG}$ antigenic sites are absent.

\section{MATERIAL AND METHODS}

\section{Reagents}

The reagents used during the study were of analytical grade and procured from standard laboratory suppliers.

\section{Experiment Animal}

The testis of Capra hircus procured from the slaughter houses near Kurukshetra $\left(29^{\circ} 6^{\prime} \mathrm{N}, 76^{\circ} 5^{\prime} \mathrm{E}\right)$ and brought to the laboratory in culture media.

\section{Histological Slides}

The testis was cut into small piecesand processed for histological slide preparation. For histological slides the tissue was fixed in aqueous Bouins fixative for 24 hours. Then tissue was washed in running tap water for 2 hours. The specimens then were dehydrated by upgrade alcohol series. After proper dehydration specimens were embedded in paraffin wax. The tissue was sectioned serially at $4 \mu \mathrm{m}$ thickness (Sharma et al., 2014). 


\section{Immunohistochemistry}

The tissue sections were deparaffinize in xylene and rehydrated by transferring slide in downgrade alcohol series. The endogenous peroxidase activity was blocked by incubating sections in $3 \% \mathrm{H}_{2} \mathrm{O}_{2}$ methanolic solution.

The sections then were rinsed in PBS. The sections on slide then incubated with Anti mouse IgG FITC conjugate antibody in a humidified chamber at room temperature. The slide was washed with PBS and then dehydrated by alcohol upgrade series. After proper dehydration sections were cleared in xylene and mounted in DPX (Biolegend, 2013).

\section{Immunofluorescence Detection}

Fluorescence was examined using Olympus fluorescence microscopes with X10 objectives. The images were corrected for brightness and contrast using Olympus Imaging Software.

\section{RESULTS}

The transverse sections of goat testis were examined to study distribution pattern of CD16, CD32 and CD64 receptors. These immnological component were found mostly towards the periphery of seminiferous Tubules. The fluorescence was observed in the interstitial components and in epithelial lining and lumen of seminiferous tubules indicates that the most of IgG antigenic immunological componentsi.e.CD16, CD32 and CD64 receptors were located in these sites. Frequency of fluorescence is higher in epithelial lining of seminiferous tubule indicated that most of the CD16, CD32 and CD64 receptors were located on this site. The $\mathrm{IgG}$ reactivity is negative inside the region of seminiferous tubule where Sertoli cells and developing spermatogonia occurs but moderate reactivity observed inside the lumen where mature spermatozoa occurred.
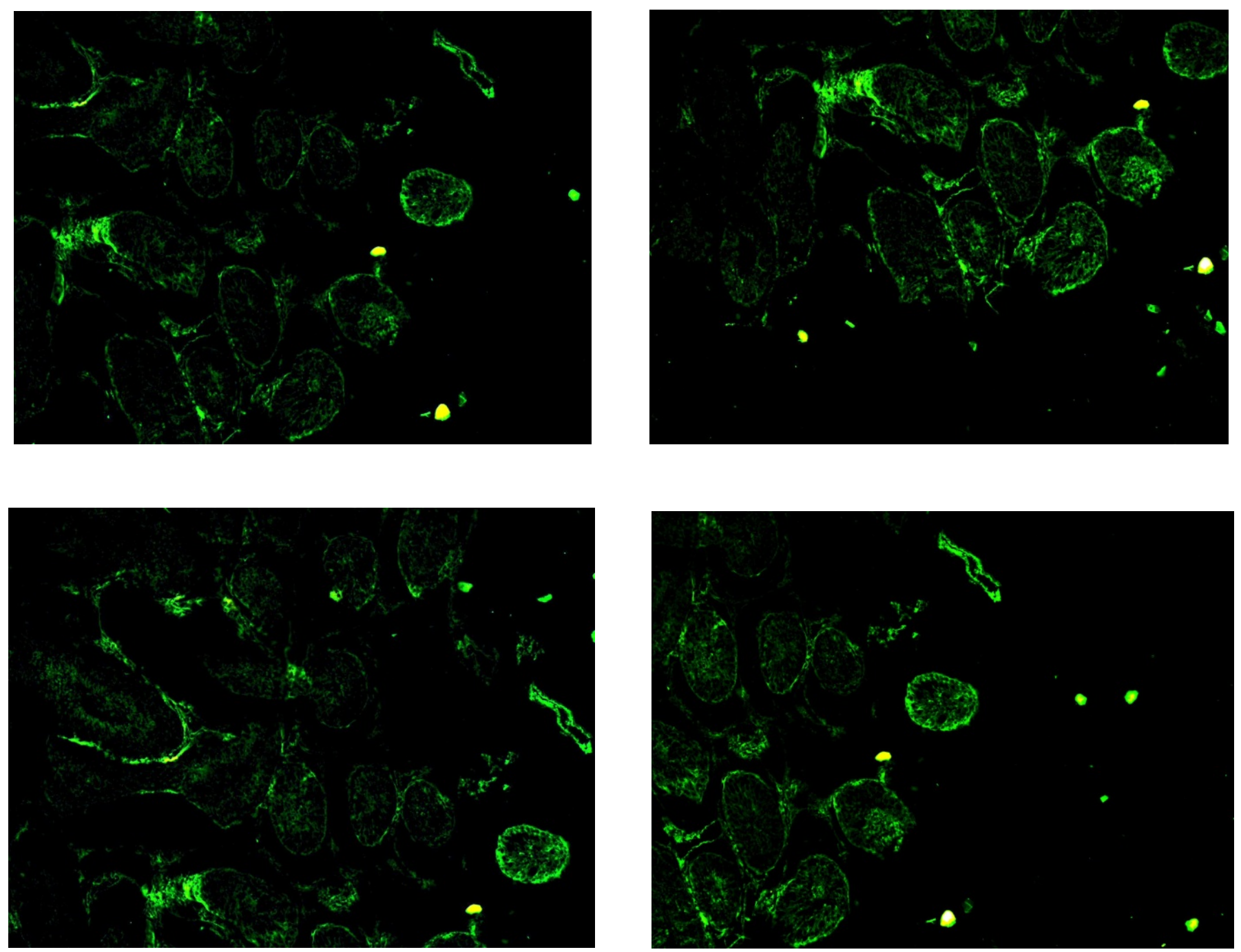

Fig. 1-4: Seminiferous tubule of goat testis showing strong reaction in the epithelial lining and moderate reaction in the lumen where mature spermatozoa occurred. The reaction is absent in the region where Sertoli cells and developing spermatogonia occurred. 
Results of present study indicate that the goat testis contains immunologically active cells which vary in numbers depending upon the location in the testis. During present study the immunological components were found to present on epithelial lining of seminiferous tubules, similar result was earlier reported. The testis provides antigenic safety/security to the dividing germ cells. Presence of Natural killer cells, macrophages have CD32 receptors have also been recorded in adluminal components (Terayama et al., 2014, Owen et al., 2004).

It is possibly because of these cells have higher fluorescence is observed around seminiferous tubules. Present research findings support the earlier studies wherein spermatogonia attached to the basal membrane of the seminiferous epithelium revealed no reactivity against goat anti-mouse $\mathrm{IgG}$ antibody but on the exposure of Busulfan small breaches occurs in blood-testis barrier and $\mathrm{IgG}$ leaks from there resulting spermatogonia showed strong reactivity to a goat anti-mouse IgG antibody (Choi et al., 2006).

\section{CONCLUSION}

Present work indicate that interstitial components and epithelial lining and lumen of seminiferous tubules are the sites where immune components i.e. CD16, CD32 and CD64 receptors are actively present. The IgG reactivity was strong in epithelial lining of seminiferous tubule and moderate in lumen but negative inside the seminiferous tubule where Sertoli cells and developing spermatogonia occurs. Present results give important information about the immuologically active location in the testicular region.Current work will help in understanding of immune privilege and provide a baseline on which further studies can be conducted.

\section{REFERENCES}

Embedded

Biolegend. 2013 Immunohistochemistry Protocol forParaffin-

Sections.http://www.biolegend.com/media_assets/support_proto col/BioLegend_IHC_Paraffin.pdf

Choi YJ, Song H, Kwon DN, Cho SK, Kang SJ, et al. 2006 Significant IgG-immunoreactivity of thespermatogonia of the germ celldepleted testis after Busulfan treatment. Animal Reproduction Science. 91317-335. doi:10.1016/j.anireprosci.2005.04.002.

Owen JA, Punt J, Stranford SA and Jones PP2013 Kuby Immunology ( $7^{\text {th }}$ Edition). W. H. Freeman and Company, New York.pp A4-A10. doi:10.1084/jem.20091739.

Sharma RK, Goyal AK, Thareja K and Bhat RA 2014Effect of nano molar concentration of methyl parathion on goat testis. International Journal of Pharmacy and Pharmaceutical Sciences. 6(2)200202.www.ijppsjournal.com/Vol6Supp12/8075.pdf.

Terayama H, Yoshimoto T, Hirai S, Naito M, Qu N, et al. 2014 Contribution of IL-12/IL-35 Common Subunit p35 to Maintaining the Testicular ImmunePrivilege. PLoS ONE. $2014 \quad 9(4)$ e96120. doi:10.1371/journal.pone.0096120.

\section{How to cite this article:}

Sharma R. K. and Goyal A.K. Localization of IgG Antigenic Sites in Goat Testicular Tissue. J App Pharm Sci, 2015; 5 (02): 120-122. 